\title{
Radionuclide distribution in tidal flat sediments of the Westerschelde estuary
}

\author{
S. Schmidt, P.M.J. Herman and J.L. Reyss \\ EDF, Laboratoire National d'Hydraulique et Environnement, \\ 6 quai Watier, 78401 Chatou cedex, France
}

\begin{abstract}
Depth profiles of the particle-reactive radionuclides ${ }^{210} \mathrm{~Pb},{ }^{137} \mathrm{Cs}$ and ${ }^{7} \mathrm{Be}$ were established in sediments of a tidal flat in the Westerschelde. Cores were collected at different seasons at selected sites with contrasting characteristics. Accumulation rates estimated from ${ }^{137} \mathrm{Cs}$ profiles are consistent between the five sites with values comprised between 1.1 at the marginal sites and $2.5 \mathrm{~cm} \mathrm{y}^{-1}$ for the central part. Although the very low level of excess ${ }^{210} \mathrm{~Pb}$ limits the precision of this method, profiles of ${ }^{210} \mathrm{~Pb}_{x 5}$ with depth allow calculating a range of sedimentation rates equivalent to those derived from ${ }^{137} \mathrm{Cs}$ data. At the muddy site, the vertical distribution of radionuclides revealed the existence of an important accumulation layer of fine particles at a depth of around $10 \mathrm{~cm}$ at the muddy site, may be in relation with biological and physical processes. The vertical distribution of ${ }^{7} \mathrm{Be}$ in the top $6 \mathrm{~cm}$ exhibits wide variability on seasonal scale, with the highest inventories and bioturbation rates observed in summer. This trend is clearly related to the seasonal variation of silt content of surface sediments.
\end{abstract}

\section{INTRODUCTION}

Estuaries play an important role in the transformation of carbon, nutrients and pollutants carried by the rivers towards the coastal sea. On short time scales, estuarine sediments can therefore act either as sources or sinks for carbon and other chemical species. On longer time scales, net accumulation usually occurs. Moreover, the material being buried may differ from that deposited due to degradation, transformation and preferential resuspension [1]. Chronologies of contaminant input are dependent on the ability to establish the depositional history of the sediment [2].

In order to assess such processes, a better knowledge of the rates of particle reworking and sedimentation is required. Combining natural and artificial radionuclides with different half-live and input, it is possible to reconstruct a detailed picture of sediment mixing and geochronology over the 10to 100 - year time $[3,4]$. We report here depth profiles of ${ }^{7} \mathrm{Be},{ }^{210} \mathrm{~Pb}$ in excess, ${ }^{137} \mathrm{Cs}$ and granulometry of a tidal flat, the Molenplaat, in the lower part of the estuary of the Westerschelde (Figure 1). Well-defined flood and ebb channels characterise this lower part, which is extending from the sea to $50 \mathrm{~km}$ from the mouth. Tidal range is around $5 \mathrm{~m}$, depending on the spring-neap tidal cycle and the wind. The period of exposure varies between $4.5 \mathrm{~h}$ and $8 \mathrm{~h}$ per tidal cycle. The objectives of this work were to quantify the rates of deposition and sediment vertical mixing of this tidal flat in relation with environmental conditions.

\section{METHOD}

On the Molenplaat tidal flat, five sites of contrasting characteristics were selected: sites 2 and 3 are in the central area of the flat, sites 1 and 4 near the gully, site 5 in the southernmost corner of the flat (Figure 1). The sites differ in the granulometry of the sediment and in the composition of the dominant fauna. Five main field campaigns have been held at the Molenplaat: June and September 1996, March, June and September 1997. At low tide cores were taken using a hand-driven tube $(1.2 \mathrm{~m}$ length $\mathrm{x} 10 \mathrm{~cm}$ inner diameter). The sediments were then sliced in 1 or $2 \mathrm{~cm}$ increments after upward extrusion of the cores and dried at $60^{\circ} \mathrm{C}$.

About $10-\mathrm{g}$ aliquots of sediment were measured directly by non-destructive gamma spectrometry to determine activities of interest. Due to the low radionuclide levels, measurements were carried out using a low-background high-efficiency well-type $\gamma$-detector (EURISYS Mesures, germanium crystal volume of $430 \mathrm{~cm}^{3}$ ) at the underground laboratory of Modane, French Alps [5]. The standards used to calibrate the $\gamma$-detector are mixtures of marine sediment with US NBS U and Th standards at $1000 \mathrm{ppm}$ for U and Thdecay series, and ${ }^{137} \mathrm{Cs}$, purchased from ORIS for ${ }^{137} \mathrm{Cs}$. Excess ${ }^{210} \mathrm{~Pb}\left({ }^{210} \mathrm{~Pb}_{x s}\right.$, non ${ }^{226} \mathrm{Ra}$ supported $\left.{ }^{210} \mathrm{~Pb}\right)$ is calculated by subtracting the activity of its parent ${ }^{226} \mathrm{Ra}$ from the total ${ }^{210} \mathrm{~Pb}$ activity. Measured $\mathrm{Be}$ activities are decay corrccted for the time elapsed between sampling and measurement. 
Granulometric composition was determined on the dried sediment samples with a Malvern particle sizer, using laser diffraction. Focal length was $300 \mathrm{~mm}$, and particle sizes in the range $0-500 \mu \mathrm{m}$ were resolved. These analyses were performed on the top $18 \mathrm{~cm}$ of the sediment cores at station 2 .

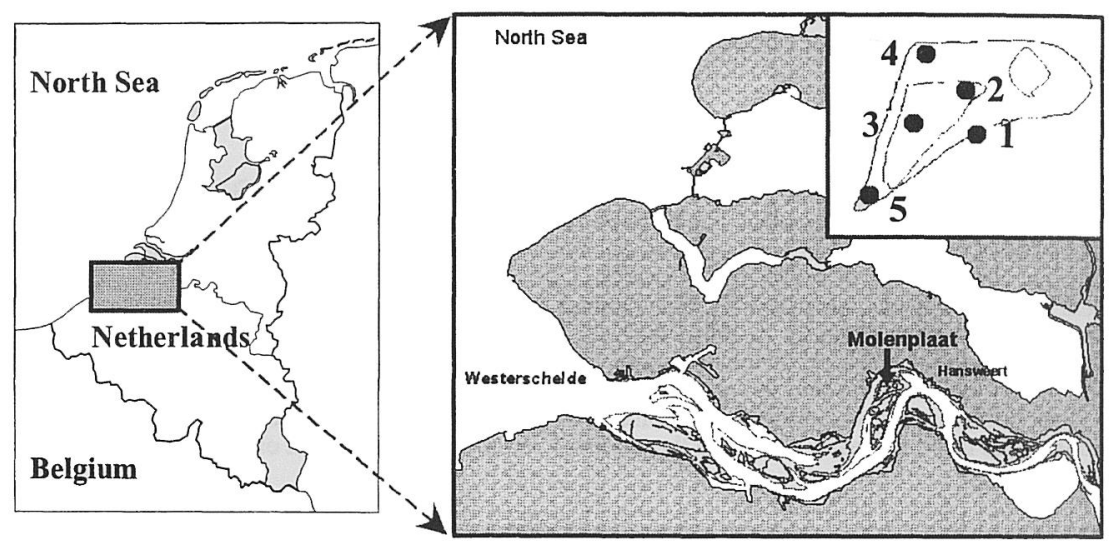

Figure 1: Map of sampling sites.
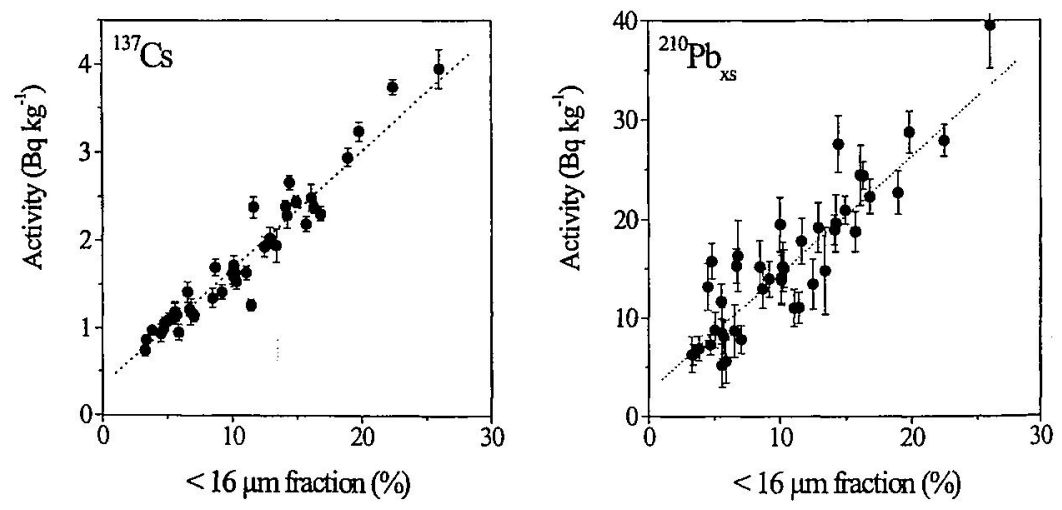

Figure 2: ${ }^{137} \mathrm{Cs}$ and ${ }^{210} \mathrm{~Pb}_{\mathrm{xs}}$ activities vs. percentage of clay fraction $(<16 \mu \mathrm{m})$.

\section{RESULTS}

There is a clear correlation between radionuclide activities and particle size. Most of ${ }^{137} \mathrm{Cs},{ }^{210} \mathrm{~Pb}_{x \mathrm{~s}}$ and ${ }^{7} \mathrm{Be}$ activities are contained in the sediment fraction smaller than $16 \mu \mathrm{m}$ (Fig. 2). This behaviour was already reported in estuarine system [6]. Such correlations between silt fractions and radionuclide activities are to be expected because these fine particles with their high surface area are the main carriers of these radionuclides.

Excess ${ }^{210} \mathrm{~Pb}$ activities were relatively low with maximum values up to $30 \mathrm{~Bq} \mathrm{~kg}^{-1}$ (Figure 3). Fo? sites 1 and 3 , total activities decreased from the sediment surface close to supported activity levels at the 
base of the core at about $1 \mathrm{~m}$ depth. The profile for site 2 was different with a rapid decrease of ${ }^{210} \mathrm{~Pb}_{\mathrm{xs}}$ activities to a minimum at $6 \mathrm{~cm}$ depth, followed by a peak at 10-12 cm depth. For the sites 4 and 5 at the edges of the tidal flat, total ${ }^{210} \mathrm{~Pb}$ activities were close to the supported activity $\left(<10 \mathrm{~Bq} \mathrm{~kg}^{-1}\right)$.

${ }^{137} \mathrm{Cs}$ data were rather similar between the different sites of the Molenplaat (Figure 3). The ${ }^{137} \mathrm{Cs}$ profile at site 2 again has higher surface activities, up to $3.5 \mathrm{~Bq} \mathrm{~kg}^{-1}$, and a sub-surface peak at about 10 $\mathrm{cm}$, as already reported for ${ }^{270} \mathrm{~Pb}_{\mathrm{xs}}$. Apart from this sub-surface maximum, common ${ }^{137} \mathrm{Cs}$ trends were low activities overall, around $1 \mathrm{~Bq} \mathrm{~kg}^{-1}$, with the appearance of a single peak at depth. The position of this deep peak varied between 34 and $82 \mathrm{~cm}$, depending on the site.
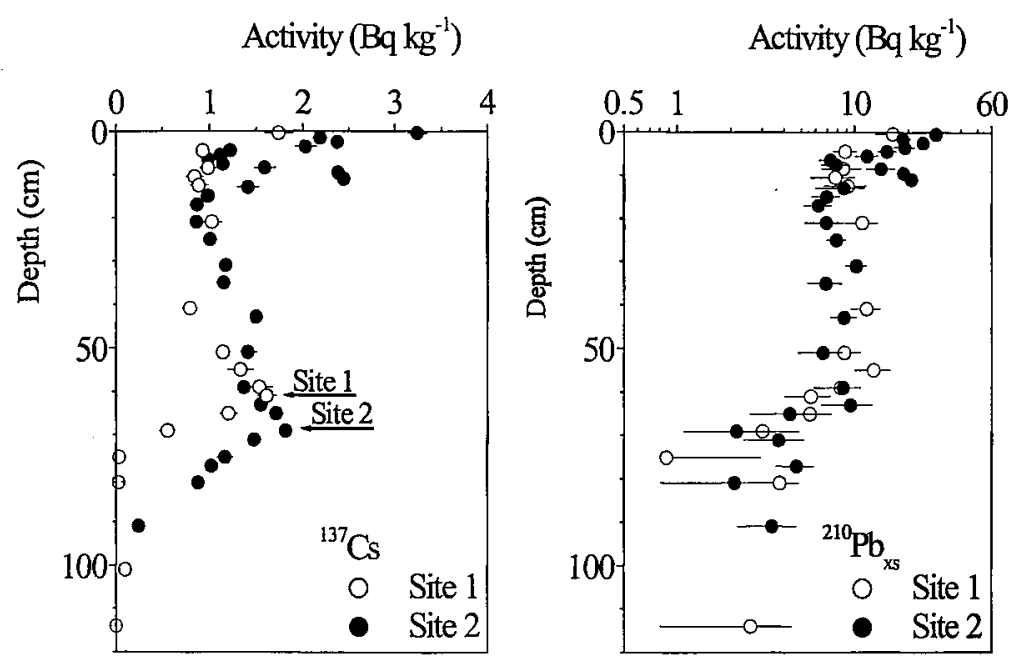

Figure 3: Profiles of ${ }^{137} \mathrm{Cs}$ and ${ }^{210} \mathrm{~Pb}$ xs with depth in the sediment: examples of sites 1 and 2. Arrows on profiles indicate deep peak of ${ }^{137} \mathrm{Cs}$.

At the muddiest site $2,{ }^{7} \mathrm{Be}$ have been always detected in the surface of all the cores. The activities decrease smoothly with depth and become undetectable below $6 \mathrm{~cm}$. These profiles suggest some bioturbation effects on the top of the sediment. In addition ${ }^{7} \mathrm{Be}$ presents a increase of activities from spring to late summer.

\section{DISCUSSION}

\subsection{Long-term sedimentation}

For the determination of long-term sedimentation rates, we used the natural isotope ${ }^{210} \mathrm{~Pb}$ and the artificial ${ }^{137} \mathrm{Cs}$. The ${ }^{210} \mathrm{~Pb}$ method is based on the measurement of the excess or unsupported activity ${ }^{210} \mathrm{~Pb}$, which is incorporated rapidly into the sediment from atmospheric fallout. Once incorporated into the sediment, unsupported ${ }^{210} \mathrm{~Pb}$ decays with depth, equivalent to time, in the sediment column according to its known half-live [7]. Under the assumption constant flux and constant sediment accumulation rate (CF: CS method) [8], the decrease of ${ }^{210} \mathrm{~Pb}_{\mathrm{ss}}$ activities with depth is described by the following relation: $\left[{ }^{210} \mathrm{~Pb}_{\mathrm{xs}}\right]_{\mathrm{z}}=$ $\left.{ }^{210} \mathrm{~Pb}_{\mathrm{xs}}\right]_{0} \exp [-\square \mathrm{z} / \mathrm{S}]$, where $\left[{ }^{210} \mathrm{~Pb}_{\mathrm{xs}}\right]_{0, z}$ are the activities of excess ${ }^{210} \mathrm{~Pb}$ at surface, or base of the mixed layer, and depth $z, \square$ is the decay constant of the nuclide, and $S$ is the sediment accumulation rate. In contrast to ${ }^{210} \mathrm{~Pb},{ }^{137} \mathrm{Cs}$ do not occur naturally: it is a product of nuclear weapons testing and power plant accidents. The first occurrence in the environment resulted from fallout of atmospheric nuclear weapons tests in the early $1950 \mathrm{~s}$, with a maximum input in 1963. More recently, in northern Europe, the Chernobyl accident in spring 1986 introduced a new ${ }^{137} \mathrm{Cs}$ input [9]. As a consequence of these distinct input events, it is possible to date sediments [10].

At site 2 , both ${ }^{210} \mathrm{~Pb}$ in excess and ${ }^{137} \mathrm{Cs}$ exhibit sub-surface maxima, which correspond to an equivalent peak in granulometry profiles. Therefore this trend can be ascribed to a local fine particle accumulation. For instance there is no clear explanation of this feature observed only at site 2 . One hypothesis is a preferential displacement of fines particles from the layer around $6 \mathrm{~cm}$ by a biological species, like Hydromaster, followed by an excretion on surface or deeper. A second hypothesis could be a 
winnowing processes in two steps: accumulation of fines particles in preferential deposition area followed by their vertical migration link to water displacement in surficial sediment during tide. Equivalent phenomena was reported for the Thau pond where Monna et al. displayed a winnowing trend of fines particles due to ripple effect in shallow waters.

Deeper in the core 2 , at about $68 \mathrm{~cm}$, only the ${ }^{137} \mathrm{Cs}$ profile present a second peak, which clearly corresponds to an input of Cs. A difference between weapon test and Chernobyl inputs is the occurrence of ${ }^{134} \mathrm{Cs}$ associated with the Chernobyl event. Indeed weapon test ${ }^{134} \mathrm{Cs}$, with its period of 2 years, have now completely disappeared after more than 30 years. The dating of this Cs peak had implied to concentrate $\mathrm{Cs}$ from a large amount of sediment of the corresponding layer. The absence of ${ }^{134} \mathrm{Cs}$ allowed to attribute the deep peak to the introduction of $\mathrm{Cs}$ by the weapon tests in the early sixties. This is confirmed by the rapid disappearance of $\mathrm{Cs}$ in the deepest part of the core. There is in fact no apparent record of the Chernobyl input at the Molenplaat. But this fallout presented a large patchiness over the northern Europe [9]. Locally Martin et al [12] observed a low transfer of Cs to the lower Westerschelde estuary.

${ }^{137} \mathrm{Cs}$ profile at site 2 leads to a mean sedimentation rate of about $2 \mathrm{~cm}$ per year. Deep cores $(40-120$ $\mathrm{m})$ have been studied the same for the other sites $(1,3,4,5)$ of the Molenplaat. Profiles of ${ }^{337} \mathrm{Cs}$ are relatively flat with the presence of the deep peak activity in depth. According to the site, this peak is observed at depth comprised between about 40 to $85 \mathrm{~cm}$, which indicates ${ }^{137}$ Cs-derived sedimentation rates comprised between 1.1 and $2.4 \mathrm{~cm} \mathrm{yr}^{-1}$ (Table 1)

Table 1: Mean sedimentation rates at each site of the Molenplaat tidal flat, derived using ${ }^{137} \mathrm{Cs}$ and ${ }^{210} \mathrm{~Pb}_{\mathrm{xs}}$ data.

\begin{tabular}{ccc}
\hline Sites & \multicolumn{2}{c}{ Sediment accumulation rate $\left(\mathrm{cm} \mathrm{yr}^{-1}\right)$ derived from } \\
\cline { 2 - 3 } & ${ }^{137} \mathrm{Cs}$ & ${ }^{210} \mathrm{~Pb}_{\mathrm{xs}}$ \\
\hline 1 & $1.8 \pm 0.1$ & 2.0 \\
2 & $2.0 \pm 0.1$ & 1.9 \\
3 & $2.4 \pm 0.2$ & 1.4 \\
4 & $1.5 \pm 0.1$ & 1.5 \\
5 & $>1.1$ & 1.2 \\
\hline
\end{tabular}

As a test for the ${ }^{137} \mathrm{Cs}$-derived sedimentation rates obtained for the Molenplaat tidal flat, we applied an independent time marker, the ${ }^{210} \mathrm{~Pb}$. The major problem was the low activities in the sediment of the Molenplaat $\left(<30 \mathrm{~Bq} \mathrm{~kg}^{-1}\right)$ by comparison with previous tidal flat studies [13]. For example, about $20 \mathrm{~km}$ upstream in the Westerschelde estuary, Zwolsman et al. [14] reported levels of ${ }^{210} \mathrm{~Pb}$ up to $200 \mathrm{~Bq} \mathrm{~kg}$ on salt-marsh sediments. It must be pointed out that measurements have been only possible because of the low-background facilities of the underground laboratory, especially for sites 4 and 5 . Nevertheless sediment accumulation rates derived from ${ }^{210} \mathrm{~Pb}_{\mathrm{xs}}$ present comparable values when compared to those derived from ${ }^{137} \mathrm{Cs}$ dating, with values between 1.2 to $2 \mathrm{~cm}$ per year (Table 1).

The sedimentation rates of the Molenplaat tidal flat, derived from radionuclide dating, are consistent with values comprised between 1.1 and $2.5 \mathrm{~cm} \mathrm{y}^{-1}$. The central sites, 2 and 3 , present the higher rates, and the marginal sites, 1 and 4 , the lower values. A mean sedimentation rate of the flat was estimated independently, based on volume differences, corrected for the subsidence due to compaction, tectonics and isostasy. This physical estimate gives an average depositional rate for the whole tidal flat of $1.3 \pm 0.1$ $\mathrm{cm} \mathrm{yr}^{-1}$ for the last 65 years [15], compatible with the radionuclide dating. Organic carbon burial rates at the Molenplaat stations, based on organic carbon content and sedimentation rates of the sediment cores, vary between 10 and $105 \mathrm{gC} \mathrm{m}^{-2} \mathrm{y}^{-1}$, which is about $30-40 \%$ of the total yearly carbon input into the sediments [16].

\subsection{Short-term sedimentation}

The cosmonucleide ${ }^{7} \mathrm{Be}$, with its short half-live $\left(t_{1 / 2}=53\right.$ days) is more suitable for the study of short-term sedimentation. In order to describe the fate of recently deposited particles, it is possible to calculate inventories and bioturbation coefficients from ${ }^{7} \mathrm{Be}$ profiles.

There is a significant variation of ${ }^{7} \mathrm{Be}$ activities in the uppermost sediments, with values increasing from around $1 \mathrm{~Bq} \mathrm{~kg}{ }^{-1}$ in spring to up to $13 \mathrm{~Bq} \mathrm{~kg}^{-1}$ late summer. ${ }^{7} \mathrm{Be}$, as ${ }^{210} \mathrm{~Pb}$ and ${ }^{137} \mathrm{Cs}$, is mainly carried by the fine particles rather than by the sandy fraction. Moreover Olsen et al [17] have observed that fine- 
particle deposition is the most important factor affecting the accumulation pattern and vertical distribution of ${ }^{7} \mathrm{Be}$ in estuarine systems. The low ${ }^{7} \mathrm{Be}$ inventories in March may indicate the disappearance of the finest fraction of the sediment (by erosion or drainage) in winter (Figure 4). On the contrary the increase of ${ }^{7} \mathrm{Be}$ inventories in summer would indicate an increase of the concentration of fine particles in the sediment.

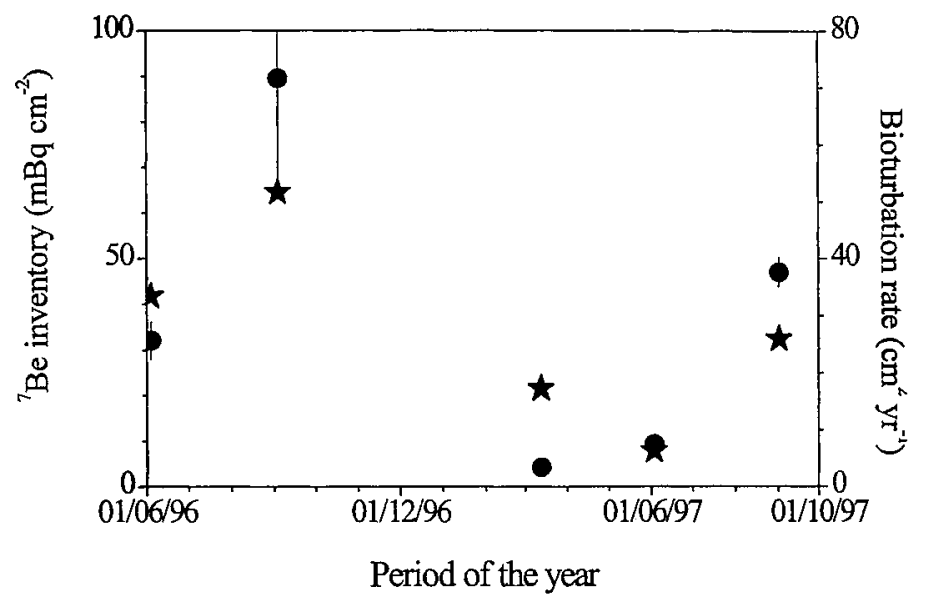

Figure 4: Temporal evolution of ${ }^{7} \mathrm{Be}$ inventory (dark points) and bioturbation rate (dark star) in the top $6 \mathrm{~cm}$ cores at site 2 of the Molenplaat tidal flat.

The simplest way to calculate bioturbation $\left(\mathrm{D}_{b}\right)$ assumes bioturbation as a diffusive process occurring at a constant intensity within a surface mixed layer [18]. Under these assumptions, evolution of ${ }^{7} \mathrm{Be}$ with depth in sediment can be describe as: $\left.\left.{ }^{7} \mathrm{Be}\right]_{\mathrm{z}}={ }^{7} \mathrm{Be}\right]_{0} \exp \left(-\left(\square / \mathrm{D}_{\mathrm{b}}\right)^{1 / 2} \mathrm{z}\right)$, where $\left.{ }^{7} \mathrm{Be}\right]_{0, z}$ are the activities of ${ }^{\prime} \mathrm{Be}$ respectively at the sediment-water interface and at the depth $\mathrm{z}, \mathrm{\square}$ is the radioactive decay constant and $\mathrm{D}_{\mathrm{b}}$ the bioturbation rate coefficient. Applied to ${ }^{7} \mathrm{Be}$ profiles obtained at the Molenplaat, bioturbation rates varied from 6 in spring (March and June, 1997) to $52 \mathrm{~cm}^{2} \mathrm{yr}^{-1}$ end summer (Sept. 97) (Figure 4). As for ${ }^{7} \mathrm{Be}$ inventories and silt content in upper sediments, $\mathrm{D}_{\mathrm{b}}$ presents a seasonal signal. This may indicate the influence of biological activity on fine particle redistribution. Indeed the biomass of suspension feeders on this tidal flat, highest at places with low bottom shear stress, present seasonal variation. The evolution of the silt content at site 2 could be also the result of biodeposition by these animals. Inventories of ${ }^{7} \mathrm{Be}$ associated with ${ }^{7} \mathrm{Be}$ derived bioturbation rate seems to indicate two processes influencing fines particles distribution in upper sediments: - erosion in winter and - bioaccumulation in summer.

\section{CONCLUSION}

This study clearly illustrates the interest of radionuclides as tracers of sedimentary pattern in estuarine environment. In particular the simultaneous use of radionuclides of different input and half-life allows to describe in details processes like sediment accumulation, bioturbation, erosion / deposition at different time scales. When considering the long-term sedimentation, using ${ }^{137} \mathrm{Cs}$ and ${ }^{210} \mathrm{~Pb}$ profiles, it is concluded that the Molenplaat tidal flat is accreting at a relatively constant rate, without strong disturbance over the past decades. But results on short-time scale point out the strong seasonality of particle deposition, in relation with erosion and biodeposition. The combination of these processes led at present to a net accumulation for the Molenplaat tidal flat. But clearly this situation could drastically change if balance is displaced toward erosion due to change in environmental forcing (effect of sea level, change in frequency/intensity of floods, biomass reduction of deposit feeders by accidental pollution, ...). Such an event would release material stored in tidal flat sediments, such fine particles, bound-particle elements or organic carbon. 


\section{Acknowledgments}

This work was a part of the ECOFLAT (Eco-Metabolism of a Tidal Flat, ENV4CT960216) project sponsored by the EU European Union ELOISE programme. We thank the underground laboratory (LSM, CNRS - CEA) and the captain and crew of the R.V. Luctor for logistic support. This is LSCE contribution 694.

\section{References}

[1] Middelburg J.J., Klaver G., Nieuwenhuize J. and Vlug T., Hydrobiol. 311 (1995) 57-69.

[2] Cochran J.K., Frignani M., Salamanca M., Belluci L.G. and Guerzoni S., Mar. Chem. 62 (1998) $15-29$.

[3] Santschi P.H., Wen L.-S. and Guo L., Mar. Chem. 73 (2001) 153-171.

[4] Schmidt S., van Weering Tj.C.E. and de Stigter H.C., Mar. Geol. 173 (2001) 55-67.

[5] Schmidt S. and Reyss J.L., J. Geophys. Res. 101 (1996) 3589-3596.

[6] Baskaran M. and Naidu A.S., Geochim. Cosmochim. Acta 59 (1995) 4435-4448.

[7] Appleby P.G. and Oldfield F., "Application of lead-210 to sedimentation studies", Uranium-series disequilibrium: Application to Earth, Marine, and Environmental Sciences (Clarendon Press, Oxford, 1992) pp. 731-778.

[8] Krishnaswamy, Lal D., Martin J.-M. and Meybeck M., Earth Planet. Sci. Lett. 11 (1971) 407-414,

[9] Callaway J.C., DeLaune R.D. and Patrick Jr. W.H., Limnol. Oceanogr. 41 (1996) 444-450.

[10] Robbins J.A., Edgington D.N. and Kemp A.L.W., Quarter. Res. 10 (1978) 256-278.

[11] Monna F., Lancelot J., Bernat M. and Mercadier H., Oceanologica Acta 20 (1997) 627-638.

[12] Martin J.-M., Wollast R., Loijens M., Thomas A., Mouchel J.M. and Nieuwenhuize J., Mar. Chem. 46 (1994) 189-202.

[13] Cundy A.B. and Croudace I.W., Mar. Chem. 51 (1995) 115-132.

[14] Zwolsman J.J.G., Berger G.W. and Van Eck G.T.M., Mar. Chem. 44 (1993), 73-94.

[15] Schmidt S., Friend P. and Herman P.M.J., "Estimate of sedimentation rates of a tidal flat: a comparison between physical and internal methods", ELOISE - European Land-Ocean Interaction Studies, 3rd Open Science Meeting Noordwijkerhout, The Netherlands, 1-4 December 1999.

[16] Schmidt S., Herman P.M.J., Middleburg J.J. and Reyss J.L., Mar. Chem. (submitted).

[17] Olsen C.R., Larsen I.L., Lowry P.D., Cutshall N.H. and Nichols M.M., J. Geophys Res. 91 (1986) 896-908.

[18] Boudreau B.P., Amer. J. Sci. 286 (1986) 161-198. 